\title{
Impact of surgery on survival in breast cancer with bone metastases only: a SEER database retrospective analysis
}

\author{
Pai Peng ${ }^{1}$, Jiang-Yuan Chen ${ }^{2 *}$, Yun-Tao Han ${ }^{1}$, Xin Chen ${ }^{3}$, Hong-Yuan Li ${ }^{3}$, Chao-Hua Hu ${ }^{1 *}$ and Jin-Li Wang ${ }^{4}$
}

\begin{abstract}
Background: It was controversial to operate on the primary site of breast cancer (BC) with bone metastasis only. We investigated the impact of surgery on BC patients with bone metastases via a SEER database retrospective analysis.

Methods: A total of 2917 BC cases with bone metastasis, first diagnosed between 2010 and 2015 in the Surveillance, Epidemiology, and Results Database (SEER) of National Cancer Institute were selected. We assessed the effect of different surgical procedures on survival and prognosis.

Results: Compared with the non-surgical group, the primary tumor surgical group showed longer median survival time $\left(X^{2}=146.023, P<0.001\right)$, and the breast-conserving subgroup showed the highest median survival time of 70 months ( $\left.X^{2}=157.117, P<0.001\right)$. Compared with the non-surgery group, the median overall survival (OS) of primary surgery group was longer $(H R=0.525,95 \% \mathrm{Cl}=0.467-0.590, \mathrm{P}<0.001)$, and the breast-conserving subgroup showed the longest median operative $\mathrm{OS}(\mathrm{HR}=0.394,95 \% \mathrm{Cl}=0.325-0.478, \mathrm{P}<0.001)$.

Conclusion: This study showed that primary surgery could improve the median survival time and OS of BC patients with bone metastasis. Moreover, under the condition of low tumor burden, breast conserving surgery was a better choice.
\end{abstract}

Keywords: Breast cancer, Bone metastases, SEER database, Primary surgery, Prognosis, Overall survival

\section{Background}

Breast cancer $(\mathrm{BC})$ is the most common malignant tumor threatening women's health, with 270,000 newly diagnosed BC patients yearly and approximately 42,000 related deaths, which ranks first in morbidity and second in mortality worldwide [1]. With the improvement of people's health awareness and the development of medical technology, the screening and treatment of early

\footnotetext{
*Correspondence: chenjiangyuan@jhun.edu.cn; huchaohua2006@126.com ${ }^{1}$ Department of Breast and Thyroid Surgery, Xiaogan Hospital Affiliated to Wuhan University of Science and Technology, Square Road No. 6 Xiaogan, Hubei, China

${ }^{2}$ School of Medicine, Jianghan University, 8 Xuefu Road, Wuhan Economic and Technological Development Zone, Wuhan, Hubei, China Full list of author information is available at the end of the article
}

$\mathrm{BC}$ have been significantly improved. However, about $5 \%$ of $\mathrm{BC}$ patients had bone metastasis at the first diagnosis, and the incidence of bone metastasis was $70 \%$ in advanced metastatic $\mathrm{BC}[2,3]$. Currently, the treatment principle for $\mathrm{BC}$ patients with bone metastasis is to relieve pain, restore function and improve the quality of life, increase the survival time, and the main comprehensive therapy includes radiation and chemotherapy [4-6].

Accumulating evidence indicates that the active primary site surgery was associated with survival benefits in many retrospective studies [7-15], although few prospective studies produced positive results [16-18]. Routine screening of bone metastases in patients with localized $\mathrm{BC}$ was not recommended by the current guideline only if signs or symptoms occurred. The effect of operation 
on the primary site of $\mathrm{BC}$ with bone metastasis is still controversial.

In this study, we used the SEER database to investigate the effect of surgical operation on the prognosis of $\mathrm{BC}$ patients with bone metastases from 2010 to 2015 .

\section{Methods}

Data

We obtained data from SEER Medicare database, which consists of 18 population-based cancer registries. The SEER program of the National Cancer Institute collects and publishes cancer incidence and survival data encompassing approximately $28 \%$ of the United States population. In this study, we used SEER*Stat Version 8.3.6 (http://www.seer.cancer.gov/seerstat) from the National Cancer Institute to survey eligible patients.

\section{Patients}

We collected BC patients with bone metastases between 2010 and 2015 based on the 7th edition of the American Joint Committee on Cancer (AJCC) Cancer Staging Manual [19]. We further screened the patients through inclusion criteria and exclusion criteria, inclusion criteria: (1) Pathological diagnosis of breast cancer; (2) Age $>18$ years old female; (3) Simple distant bone metastases occurred clearly at the first diagnosis; (4) Complete clinicopathological information such as tumor pathological type and histological grade; (5) Complete treatment information; (6) Prognostic information is complete. Exclusion criteria: (1) Multiple primary carcinomas; (2) Bilateral breast cancer; (3) Patients with unknown $\mathrm{T}$ and $\mathrm{N}$ stages, such as T0,TX and NX, were excluded. After relevant screening, we finally leaved 2917 patients eligible for survival analyses and related research.

\section{Clinicopathological parameters and control variables}

Patients were divided into primary surgery group and non-surgery group. The Surgery group was divided into Breast Conservion Surgery (BCS) group, subcutaneous or simple Mastectomy group (Mastectomy), modified Radical Mastectomy group and Radical Mastectomy group (Radical mastectomy). Clinical pathology staging was based on AJCC 7th edition. The following clinicopathological characteristics were used as study factors: age, race, ethnic origin, marital status, $\mathrm{T}$ stage, $\mathrm{N}$ stage, laterality, behavior, ER, PR, HER2, tumor subtype and histological grade, radiotherapy, and chemotherapy.

\section{Statistical analysis}

Patient and tumor characteristics were summarized using descriptive statistics and compared using a two-sided $\chi^{2}$ test for categorical variables and Student's t test for continuous variables. In the survival analysis, Kaplan-Meier method was used to calculate the median survival time, and log-rank test was used for univariate analysis. Statistically significant factors in univariate analysis results were incorporated into COX proportional hazard regression model for multivariate analysis. All the above statistical analyses were calculated by SPSS 22.0 statistical software. Two-sided $\mathrm{P}$ values $<0.05$ were considered statistically significant.

\section{Results}

\section{Patient characteristics}

A total of 2917 BC patients with bone metastasis only were included in this study, and clinical characteristics were listed in Table 1 . The primary surgery group included 1245 cases $(42.7 \%, 1235 / 2917)$, and the non-surgery group consisted of 1672 cases $(57.3 \%, 1672 / 2917)$. The clinicopathological parameters showed significant differences between two groups included marital status, age, histological grade, $\mathrm{T}$ stage, $\mathrm{N}$ stage, ER, molecular subtype, radiotherapy and chemotherapy. Compared with the non-operative patients, the proportion of young patients undergoing surgery was higher $\left(x^{2}=21.613\right.$, $\mathrm{P}<0.001)$. Compared with unmarried patients, married patients had a higher surgical rate $(46.8 \%$ vs $38.8 \%)$. Patients in advanced stage had more ratio of radiotherapy and chemotherapy. Compared with ER positive, ER+ / HER2 - and ER + /HER2 + patients, ER negative, TNBC, and HER2-enriched $B C$ patients had higher surgical rate $(\mathrm{P}<0.001$ and $\mathrm{P}=0.009)$. There were no significant differences in race, Ethnic origin, behavior, laterality, HER2 and PR expression between the two groups.

\section{Univariate analysis and multivariate analysis on the prognosis of $\mathrm{BC}$ with bone metastasis}

Univariate analysis was performed for the 2917 cases (Table 2), and the clinicopathological parameters influencing the prognosis of patients were race, histologic grade, marital status, age, histology, T stage, tumor radiotherapy and chemotherapy, ER, PR, and HER2, subtypes, primary tumors surgery and surgical procedure $(\mathrm{P}<0.05)$. Ethnic origin, laterality, and $\mathrm{N}$ staging showed no significant difference $(P>0.05)$. According to the results of univariate analysis, primary site surgical group significantly affected the prognosis of patients (Fig. 1) compared to the non-surgical group $\left(X^{2}=146.023, P<0.001\right)$; Among the surgery group, the survival time of the breast-conserving group (Fig. 2) benefitted most for 70 months $\left(\chi^{2}\right.$ $=157.117, \mathrm{P}<0.001)$. Advanced stage patients showed decreased median survival time $(\mathrm{P}<0.001)$. Compared with the black, the white and others got a longer survival time $\left(X^{2}=35.071, P<0.001\right)$; The expression of ER, PR, and HER2, histology of invasive ductal carcinoma, married patients, younger age, radiotherapy, and 
Table 1 The baseline level of 2917 patients

\begin{tabular}{|c|c|c|c|c|c|}
\hline Variables & Number & Surgery (\%) & Non-surgery (\%) & $x^{2}$ & P-value \\
\hline \multicolumn{6}{|l|}{ Race } \\
\hline White & 2255 & $968(42.9 \%)$ & $1287(57.1 \%)$ & 0.567 & 0.753 \\
\hline Black & 462 & $190(41.1 \%)$ & $272(58.9 \%)$ & & \\
\hline Other & 200 & $87(43.5 \%)$ & $113(56.5 \%)$ & & \\
\hline \multicolumn{6}{|l|}{ Ethnic origin } \\
\hline Spanish-Hispanic-Latino & 289 & $136(47.1 \%)$ & $153(52.9 \%)$ & 2.513 & 0.113 \\
\hline Non-Spanish-Hispanic-Latino & 2628 & 1109 (42.2\%) & $1519(57.3 \%)$ & & \\
\hline \multicolumn{6}{|l|}{ Age } \\
\hline$\leq 35$ & 134 & $67(50 \%)$ & $67(50 \%)$ & 21.613 & $<0.001$ \\
\hline $35<$ Age $<60$ & 1345 & $631(46 \%)$ & 714 (54\%) & & \\
\hline$\geq 60$ & 1438 & $547(38 \%)$ & $891(62)$ & & \\
\hline \multicolumn{6}{|l|}{ Marital status } \\
\hline Married & 1416 & $662(46.8 \%)$ & $754(53.2 \%)$ & 18.638 & $<0.001$ \\
\hline Unmarried & 1501 & $583(38.8 \%)$ & $918(61.2 \%)$ & & \\
\hline \multicolumn{6}{|l|}{ Grade } \\
\hline 1 & 287 & $99(34.5 \%)$ & $188(65.5 \%)$ & 37.276 & $<0.001$ \\
\hline 2 & 1440 & $560(38.9 \%)$ & $880(68.1 \%)$ & & \\
\hline $3-4$ & 1190 & $586(49.2 \%)$ & $604(50.8 \%)$ & & \\
\hline \multicolumn{6}{|l|}{ Laterality } \\
\hline Left & 1525 & $656(43 \%)$ & $869(57 \%)$ & 0.147 & 0.701 \\
\hline Right & 1392 & $589(42.3 \%)$ & 803 (57.7\%) & & \\
\hline \multicolumn{6}{|l|}{ Histology } \\
\hline IDC & 2351 & 1023 (43.5\%) & 1328 (56.5\%) & 3.433 & 0.064 \\
\hline Non-IDC & 566 & $222(39.2 \%)$ & 344 (60.8\%) & & \\
\hline \multicolumn{6}{|l|}{ Tstage } \\
\hline $\mathrm{T} 1$ & 383 & $153(39.9 \%)$ & $230(60.1 \%)$ & 45.68 & $<0.001$ \\
\hline $\mathrm{T} 2$ & 1158 & $569(49.1 \%)$ & 589 (50.9\%) & & \\
\hline T3 & 553 & $242(43.8 \%)$ & 311 (56.2\%) & & \\
\hline T4 & 823 & $281(34.1 \%)$ & 542 (65.9\%) & & \\
\hline \multicolumn{6}{|l|}{ Nstage } \\
\hline NO & 704 & $208(29.5 \%)$ & 496 (70.5\%) & 258.366 & $<0.001$ \\
\hline N1 & 1326 & $463(34.9 \%)$ & 863 (65.1\%) & & \\
\hline $\mathrm{N} 2$ & 406 & $261(64.3 \%)$ & $145(35.7)$ & & \\
\hline N3 & 481 & $313(65.1 \%)$ & 168 (34.9\%) & & \\
\hline \multicolumn{6}{|l|}{ Radiation } \\
\hline Yes & 1302 & 704 (54.1\%) & 598 (45.9\%) & 124.703 & $<0.001$ \\
\hline No & 1615 & $541(33.5 \%)$ & 1074 (66.5\%) & & \\
\hline \multicolumn{6}{|l|}{ Chemotherapy } \\
\hline Yes & 1564 & $803(51.3 \%)$ & 761 (48.7\%) & 103.411 & $<0.001$ \\
\hline No & 1353 & $442(32.7 \%)$ & 911 (67.3\%) & & \\
\hline \multicolumn{6}{|l|}{ Subtype } \\
\hline $\mathrm{ER}+/ \mathrm{HER} 2-$ & 2114 & $869(41.1 \%)$ & 1245 (58.9\%) & 11.671 & 0.009 \\
\hline ER +/HER2 + & 433 & $189(43.6 \%)$ & 244 (56.4\%) & & \\
\hline HER2 + & 122 & $61(50 \%)$ & $61(50 \%)$ & & \\
\hline TNBC & 248 & $126(50.8 \%)$ & 122 (49.2\%) & & \\
\hline \multicolumn{6}{|l|}{$E R$} \\
\hline Positive & 2532 & 1050 (41.5\%) & $1482(58.5 \%)$ & 11.512 & 0.001 \\
\hline Negative & 385 & $195(50.6 \%)$ & 190 (49.4\%) & & \\
\hline \multicolumn{6}{|l|}{$P R$} \\
\hline Positive & 2121 & 886 (41.8\%) & 1235 (58.2\%) & 2.62 & 0.106 \\
\hline
\end{tabular}


Table 1 (continued)

\begin{tabular}{|c|c|c|c|c|c|}
\hline Variables & Number & Surgery (\%) & Non-surgery (\%) & $x^{2}$ & P-value \\
\hline Negative & 796 & $359(45.1 \%)$ & $437(54.9 \%)$ & & \\
\hline \multicolumn{6}{|l|}{ HER2 } \\
\hline Positive & 555 & $250(45 \%)$ & $305(55 \%)$ & 1.566 & 0.211 \\
\hline Negative & 2362 & 995 (42.1\%) & 1367 (57.9\%) & & \\
\hline
\end{tabular}

ER estrogen receptor, $P R$ progesterone receptor, Her-2 human epidermal growth factor receptor 2, IDC infiltrating ductal carcinoma, TNBC triple-negative breast cancer

chemotherapy were all protective factors for $\mathrm{BC}$ with bone metastasis $(\mathrm{P}<0.001)$. Univariate analysis showed that her2-positive $\mathrm{BC}$ had the best prognosis, with the median survival time up to 73 months, while TNBC had the worst prognosis, with the median survival time of 13 months. COX multivariate regression analysis was performed based on the pathological parameters screened by univariate analysis (Table 3 ). The results showed that the clinicopathological parameters with significant differences between the two groups included race, age, marital status, histological grade, histology, chemotherapy, ER, PR, HER2, molecular subtype, $T$ stage, primary surgery and surgical mode. The results of univariate analysis were consistent with COX multivariate regression analysis except the slight change of radiotherapy factors.

\section{Comparison of baseline data among 1245 patients with different surgical modes}

To further analyze the difference in survival analysis among different surgical methods, we used $x^{2}$ test to further analyze the baseline data of 1245 patients with different surgical methods (Table 4). T staging, N staging, radiotherapy and chemotherapy showed significant differences $(P<0.05)$ in baseline data of 1245 patients, while no significant differences in other variables were found. In the BCS group, the proportion of $\mathrm{T}$ and $\mathrm{N}$ stages, radiotherapy and chemotherapy was higher: the clinical stages were lower, the tumor burden was lower, and the treatment was more active.

\section{Discussion}

De novo stage IV BC refers to a tumor that has metastasized to other organs of the body with poor prognosis. The therapeutic goal is to improve the OS and the quality of life of patients, and systemic treatment is the first choice. The intervention guideline of local surgery for $\mathrm{BC}$ is to relieve symptoms, remove tumor rupture, bleeding, fungal infection and cancer pain without affecting the life of the patient [6].

In our study, the pathology of $\mathrm{BC}$ patients with bone metastasis was mostly LuminalA type (ER+/HER2-) (72.5\%), which had good prognosis due to the stable endocrine therapy and low proliferative index. Primary site surgical group significantly affected the prognosis of patients (Fig. 1) compared to the non-surgical group $\left(x^{2}=146.023, P<0.001\right)$, benefitting most for 70 months in BCS subgroup (Fig. 2) $\left(X^{2}=157.117, \mathrm{P}<0.001\right)$. The expression of ER, PR, and HER2, histology of invasive ductal carcinoma, married patients, younger age, radiotherapy, and chemotherapy were all protective factors for $\mathrm{BC}$ with bone metastasis $(\mathrm{P}<0.001)$. Although the treatment of $\mathrm{BC}$ is surgery-based comprehensive treatment, the survival benefit from primary surgery may be related to the following conditions: (1) Surgery could remove the primary tumor site, get rid of the primary tumor cell and tumor stem cells, and reduce the possibility of peripheral release and spread of circulating tumor cells [20-22]; (2) Primary surgery could play an important role at local control of patients: tumor ulcer, infection and other aspects, which improved patients' physical and psychological quality of life; (3) Primary surgery could reduce the burden of tumor and improve the curative effect of tumor chemotherapy [23, 24]; (4) Resection of the primary tumor could reduce the immune suppression of the tumor on the body, activate CD4 and CD8 T lymphocytes, and stimulate the immune response of the body to tumor cells $[12,25,26]$.

In the past related studies about advanced invasive carcinoma $[23,27,28]$, a phenomenon had been observed in gastric cancer, ovarian cancer, colon cancer that the reduction in tumor burden and an increase in OS were associated, but it was controversial that surgery did not take a survival benefit in de novo stage IV BC [5, 16-18]. However, in recent years, some retrospective studies [7-15] had shown that resection of the primary site of de novo stage IV BC could bring survival benefits, which were most obvious in young patients with positive estrogen receptor, low tumor burden, negative human epidermal growth factor receptor, and bone metastasis only.

We analyzed previous prospective clinical studies. Firstly, the Translational Breast Cancer Research Consortium 013 (TBCRC-013 study) was a prospective multi-institutional registry trial which aimed to evaluate the role of surgery in stage IV breast cancer. Patients diagnosed with stage IV BC at presentation (group A, $n=112$ ) or stage IV within 3 months of diagnosis (group 
Table 2 Univariate analysis of clinical pathology and prognosis of 2917 BC patients with bone metastasis

\begin{tabular}{|c|c|c|c|c|c|}
\hline Variables & Number & $\begin{array}{l}\text { Median survival time } \\
\text { (month) }\end{array}$ & $\begin{array}{l}\text { 95\% confidence interval } \\
\text { (Cl) }\end{array}$ & $x^{2}$ & P-value \\
\hline \multicolumn{6}{|l|}{ Race } \\
\hline White & 2255 & 44 & $41.617-46.383$ & 35.071 & $<0.001$ \\
\hline Black & 462 & 31 & $27.607-34.393$ & & \\
\hline Other & 200 & 43 & $31.973-54.027$ & & \\
\hline \multicolumn{6}{|l|}{ Grade } \\
\hline 1 & 287 & 46 & $37.721-54.279$ & & \\
\hline 2 & 1440 & 46 & $42.998-49.002$ & 45.128 & $<0.001$ \\
\hline $3-4$ & 1190 & 34 & $31.198-37.002$ & & \\
\hline \multicolumn{6}{|l|}{ Marital } \\
\hline Married & 1416 & 48 & $44.517-51.483$ & 45.771 & $<0.001$ \\
\hline Unmarried & 1501 & 36 & $33.209-38.791$ & & \\
\hline \multicolumn{6}{|l|}{ Age } \\
\hline$\leq 35$ & 134 & 56 & $38.548-73.452$ & & \\
\hline $35<$ age $<60$ & 1345 & 46 & $42.387-49.613$ & 70.468 & $<0.001$ \\
\hline$\geq 60$ & 1438 & 36 & $33.066-38.934$ & & \\
\hline \multicolumn{6}{|l|}{ Ethnic origin } \\
\hline Spanish-Hispanic-Latino & 289 & 47 & $41.597-52.403$ & 2.103 & 0.147 \\
\hline Non-Spanish-Hispanic-Latino & 2628 & 41 & $38.983-43.017$ & & \\
\hline \multicolumn{6}{|l|}{ Laterality } \\
\hline Left & 1525 & 42 & $39.446-44.554$ & 0.017 & 0.896 \\
\hline Right & 1392 & 42 & $39.085-44.915$ & & \\
\hline \multicolumn{6}{|l|}{ Histology } \\
\hline IDC & 2351 & 44 & $41.537-46.463$ & 25.295 & $<0.001$ \\
\hline Non-IDC & 566 & 36 & $32.245-39.755$ & & \\
\hline \multicolumn{6}{|l|}{ Tstage } \\
\hline $\mathrm{T} 1$ & 383 & 47 & $38.824-55.176$ & & \\
\hline $\mathrm{T} 2$ & 1158 & 47 & $42.855-51.145$ & 53.468 & $<0.001$ \\
\hline T3 & 553 & 40 & $35.692-44.308$ & & \\
\hline T4 & 823 & 34 & $30.984-37.016$ & & \\
\hline \multicolumn{6}{|l|}{ Nstage } \\
\hline No & 704 & 39 & $34.668-43.332$ & & \\
\hline N1 & 1326 & 43 & $39.941-46.059$ & 5.582 & 0.134 \\
\hline N2 & 406 & 43 & $37.639-48.361$ & & \\
\hline N3 & 481 & 42 & $38.004-45.996$ & & \\
\hline \multicolumn{6}{|l|}{ Radiation } \\
\hline Yes & 1302 & 46 & $42.593-49.407$ & 14.906 & $<0.001$ \\
\hline No & 1615 & 39 & $36.512-41.488$ & & \\
\hline \multicolumn{6}{|l|}{ Chemotherapy } \\
\hline Yes & 1564 & 48 & $44.242-51.758$ & 64.579 & $<0.001$ \\
\hline No & 1353 & 36 & $33.254-38.746$ & & \\
\hline \multicolumn{6}{|l|}{ Subtype } \\
\hline $\mathrm{ER}+/ \mathrm{HER} 2-$ & 2114 & 43 & $41.030-44.970$ & & \\
\hline $\mathrm{ER}+/ \mathrm{HER} 2+$ & 433 & 57 & $48.725-65.275$ & 242.199 & $<0.001$ \\
\hline HER2 + & 122 & 73 & 0 & & \\
\hline TNBC & 248 & 13 & $11.349-14.651$ & & \\
\hline \multicolumn{6}{|l|}{$E R$} \\
\hline Positive & 2532 & 44 & $42.077-45.923$ & 91.338 & $<0.001$ \\
\hline Negative & 385 & 18 & 14.319-21.681 & & \\
\hline$P R$ & & & & & \\
\hline
\end{tabular}


Table 2 (continued)

\begin{tabular}{|c|c|c|c|c|c|}
\hline Variables & Number & $\begin{array}{l}\text { Median survival time } \\
\text { (month) }\end{array}$ & $\begin{array}{l}95 \% \text { confidence interval } \\
\text { (CI) }\end{array}$ & $x^{2}$ & P-value \\
\hline Positive & 2121 & 46 & $43.765-48.235$ & 97.923 & $<0.001$ \\
\hline Negative & 796 & 27 & $23.973-30.027$ & & \\
\hline \multicolumn{6}{|l|}{ HER2 } \\
\hline Positive & 555 & 58 & 46.618-69.382 & 30.843 & $<0.001$ \\
\hline Negative & 2362 & 40 & $37.931-42.069$ & & \\
\hline \multicolumn{6}{|l|}{ Primary surgery } \\
\hline Operation & 1245 & 56 & $51.508-60.492$ & 146.023 & $<0.001$ \\
\hline Non-operation & 1672 & 33 & $30.830-35.170$ & & \\
\hline \multicolumn{6}{|l|}{ Surgical mode } \\
\hline Non-operation & 1672 & 33 & $30.830-35.170$ & & \\
\hline $\mathrm{BCS}$ & 381 & 70 & 0 & 157.117 & $<0.001$ \\
\hline Mastectomy & 255 & 59 & $45.751-72.249$ & & \\
\hline Radical mastectomy & 609 & 48 & $43.369-52.631$ & & \\
\hline
\end{tabular}

$E R$ estrogen receptor, $P R$ progesterone receptor, Her-2 human epidermal growth factor receptor $2, I D C$ infiltrating ductal carcinoma, $B C S$ breast conserving surgery, $T N B C$ triple-negative breast cancer

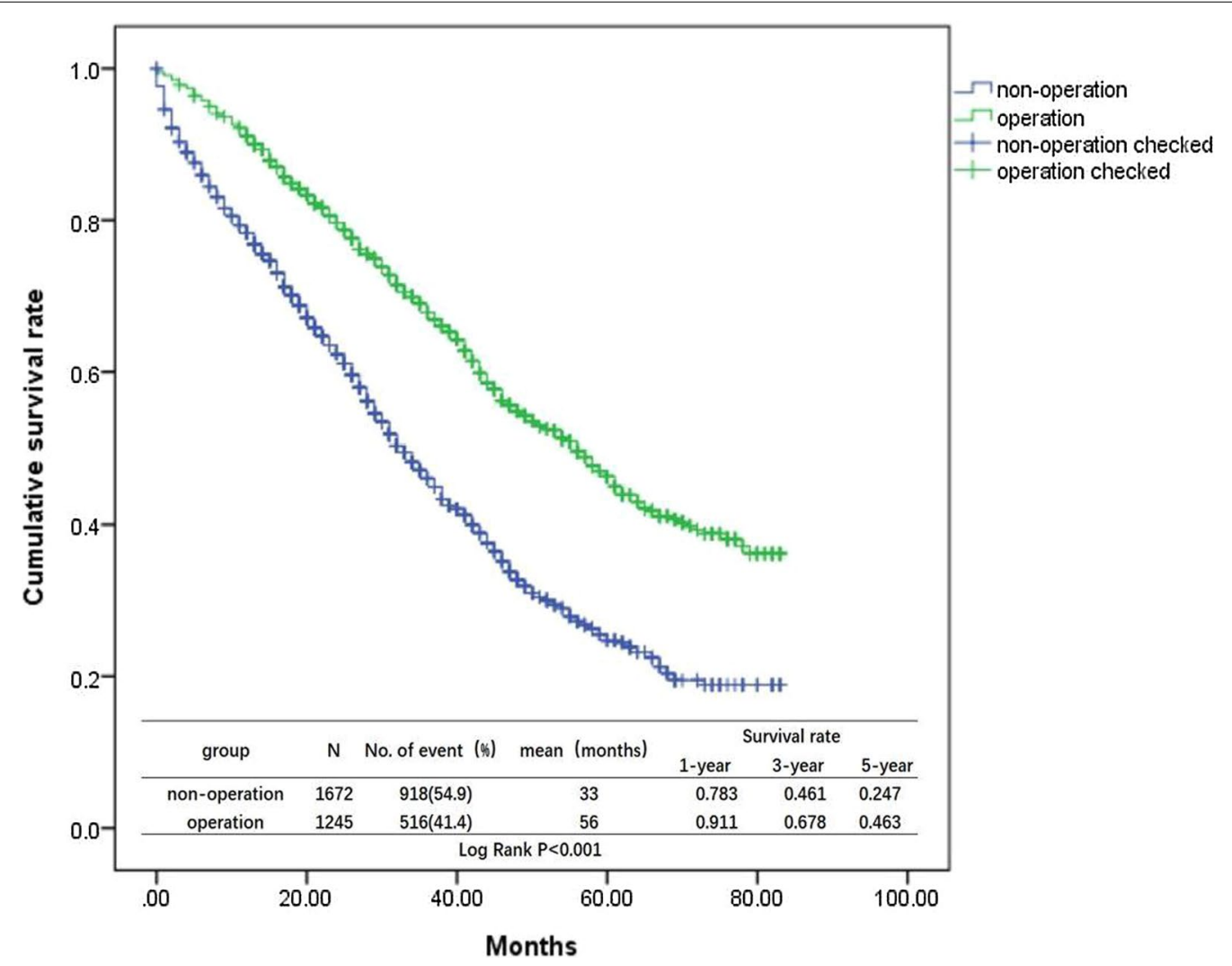

Fig. 1 Survival curves for non-operation vs operation 


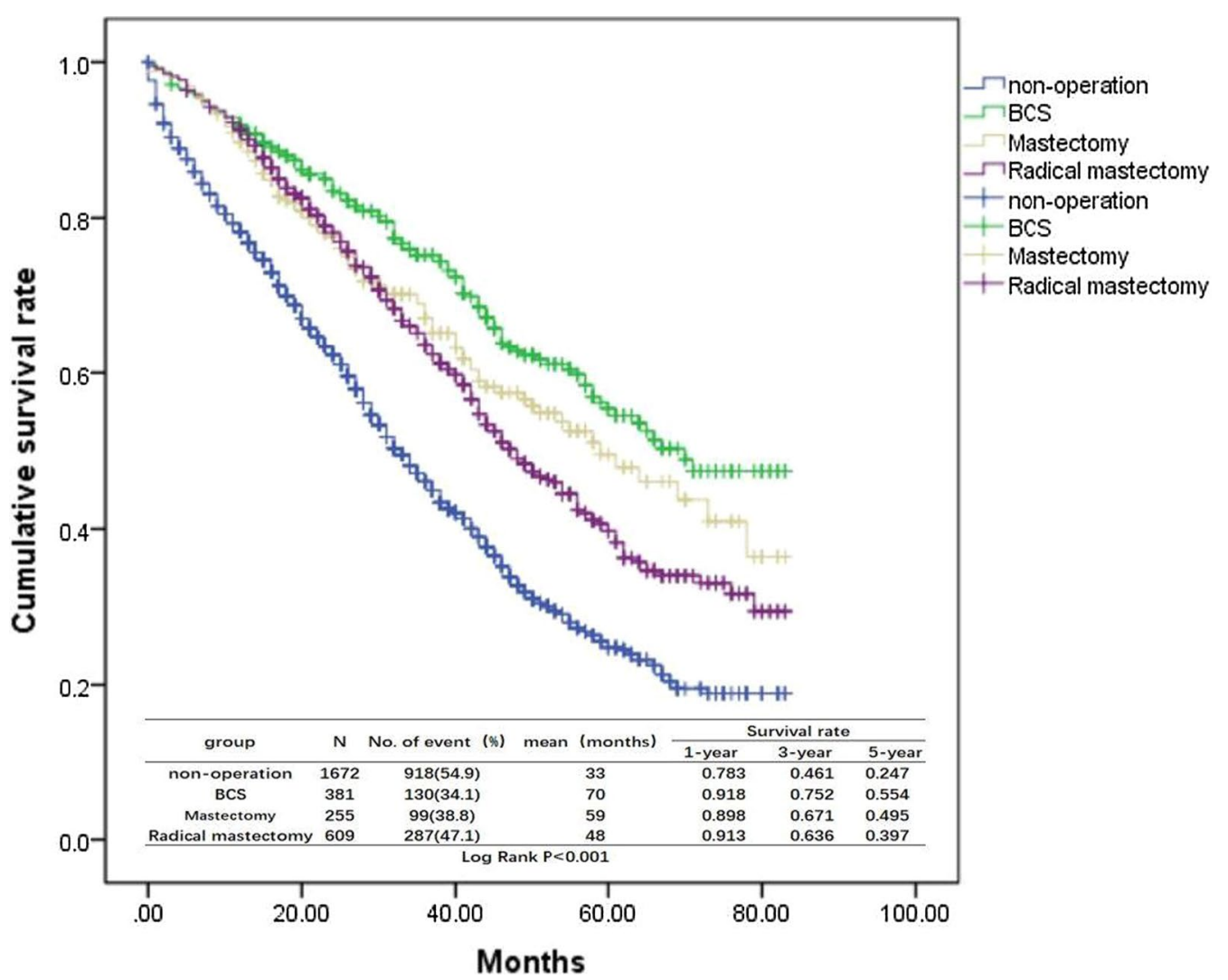

Fig. 2 Survival curves for non-operation vs different surgical modes

$B, n=16$ ) were enrolled. Early results [29] from this study showed that surgery was associated with improved survival on multivariate analysis (HR $0.28,95 \%$ CI $0.10-0.74$, $\mathrm{P}=0.01$ ); In addition, 3-year overall survival results showed no difference among patients who responded to first-line therapy [16]. Secondly, the prospective clinical trial was initiated at Tata Memorial Centre in India enrolling 350 patients to receive locoregional treatment $(n=173)$ or no locoregional treatment $(n=177)$. The result indicated the surgery could not take survival benefit because of unreasonable systemic therapy. In their study, most patients (92\%) with HER2-positive BC did not receive trastuzumab therapy; In addition, they had more metastases ratio ( $75 \%$ vs $25 \%$ ) while less bone metastases ratio (29\%) [17]. At last, the MF07-01 trial conducted by the Turkish Federation seemed to produce positive result. OS was improved for the surgery group at $41.6 \%$ as compared to $24.4 \%$ in the no surgery group at 5 years. (46 versus 37 months, $\mathrm{P}=0.005$ ). Subgroup analysis showed that the survival benefit was associated with ER positive and HER2/neu-negative disease, age under 55 , and bone metastases only [18].

Different primary tumor surgery methods took different survival benefit, which might be associated with baseline of patients in terms of $\mathrm{T}$ stage, $\mathrm{N}$ stage, chemotherapy, radiation therapy. There was lower tumor load, $\mathrm{T}$ stage, $\mathrm{N}$ stage levels and higher proportion of chemotherapy, radiation therapy in the BCS group, consistent with the fact that the prognosis was better in patients with bone metastasis only from BC with a lower tumor burden. Expanding the scope of surgery and lymph node dissection showed that there was no significant survival benefit $[7,30,31]$, consistent with the results of multifactor analysis in our study, but surgical margin status was correlated with patient prognosis[7]. In addition, Her-2 overexpression was statistically significant in univariate and multivariate analyses $(\mathrm{P}<0.05)$, and Her-2 overexpression might be a protective factor affecting $\mathrm{BC}$ bone metastasis, which might be related to anti-Her-2 targeted therapy [32, 33].

Some limitations still exist in this study. Firstly, we are lack of the comprehensive information about systemic treatment, such as endocrine therapy, HER2-targeted therapy, or chemotherapy, which might lead to some bias in the survival analysis. Also, the short of data in the SEER database on events associated with bone metastasis as well as related systematic treatment [34-36] might lead to bias in the conclusions. Another potential issue is 
Table 3 Multivariate analysis of clinical pathology and prognosis of 2917 BC patients with bone metastasis

\begin{tabular}{|c|c|c|c|c|c|}
\hline Variables & Regression coefficient & Standard error & P-value & HR & $95 \% \mathrm{Cl}$ \\
\hline \multicolumn{6}{|l|}{ Marital } \\
\hline Married & Reference & & & & \\
\hline Unmarried & 0.193 & 0.056 & 0.001 & 1.213 & $1.087-1.354$ \\
\hline \multicolumn{6}{|l|}{ Age } \\
\hline$\leq 35$ & Reference & & & & \\
\hline $35<$ age $<60$ & -0.07 & 0.147 & 0.635 & 0.933 & $0.700-1.243$ \\
\hline$\geq 60$ & 0.258 & 0.147 & 0.08 & 1.294 & $0.970-1.727$ \\
\hline \multicolumn{6}{|l|}{ Race } \\
\hline White & Reference & & & & \\
\hline Black & 0.267 & 0.071 & $<0.001$ & 1.306 & $1.135-1.502$ \\
\hline Other & 0.001 & 0.113 & 0.995 & 1.001 & $0.802-1.248$ \\
\hline \multicolumn{6}{|l|}{ Histology } \\
\hline IDC & Reference & & & & \\
\hline Non-IDC & 0.331 & 0.065 & $<0.001$ & 1.392 & $1.225-1.583$ \\
\hline \multicolumn{6}{|l|}{ Primary surgery } \\
\hline Non-operation & Reference & & & & \\
\hline Operation & -0.644 & 0.059 & $<0.001$ & 0.525 & $0.467-0.590$ \\
\hline \multicolumn{6}{|l|}{ Chemotherapy } \\
\hline Yes & Reference & & & & \\
\hline No & 0.383 & 0.061 & $<0.001$ & 1.467 & $1.302-1.653$ \\
\hline \multicolumn{6}{|l|}{ Tstage } \\
\hline $\mathrm{T} 1$ & Reference & & & & \\
\hline $\mathrm{T} 2$ & 0.116 & 0.091 & 0.2 & 1.123 & $0.940-1.341$ \\
\hline T3 & 0.247 & 0.099 & 0.013 & 1.28 & $1.054-1.555$ \\
\hline T4 & 0.321 & 0.093 & 0.001 & 1.379 & $1.149-1.654$ \\
\hline \multicolumn{6}{|l|}{ Radiation } \\
\hline Yes & Reference & & & & \\
\hline No & -0.011 & 0.055 & 0.849 & 0.99 & $0.888-1.103$ \\
\hline \multicolumn{6}{|l|}{ Grade } \\
\hline 1 & Reference & & & & \\
\hline 2 & 0.234 & 0.1 & 0.02 & 1.263 & $1.038-1.538$ \\
\hline $3-4$ & 0.583 & 0.105 & $<0.001$ & 1.791 & $1.459-2.199$ \\
\hline \multicolumn{6}{|l|}{ HER2 } \\
\hline Positive & Reference & & & & \\
\hline Negative & 0.571 & 0.082 & $<0.001$ & 1.771 & $1.508-2.079$ \\
\hline \multicolumn{6}{|l|}{$E R$} \\
\hline Positive & Reference & & & & \\
\hline Negative & 0.589 & 0.095 & $<0.001$ & 1.802 & $1.496-2.170$ \\
\hline \multicolumn{6}{|l|}{$P R$} \\
\hline Positive & reference & & & & \\
\hline Negative & 0.442 & 0.073 & $<0.001$ & 1.556 & $1.348-1.797$ \\
\hline \multicolumn{6}{|l|}{ Subtype } \\
\hline ER +/HER2- & Reference & & & & \\
\hline ER +/HER2 + & -0.243 & 0.091 & 0.007 & 0.785 & $0.657-0.937$ \\
\hline HER2 + & -2.024 & 0.353 & $<0.001$ & 0.132 & $0.066-0.264$ \\
\hline TNBC & -0.547 & 0.322 & 0.089 & 0.579 & $0.308-1.088$ \\
\hline \multicolumn{6}{|l|}{ Surgical mode } \\
\hline Non-operation & Reference & & & & \\
\hline $\mathrm{BCS}$ & -0.93 & 0.099 & $<0.001$ & 0.394 & $0.325-0.478$ \\
\hline Mastectomy & -0.702 & 0.108 & $<0.001$ & 0.496 & $0.401-0.613$ \\
\hline Radical mastectomy & -0.488 & 0.071 & $<0.001$ & 0.614 & $0.534-0.706$ \\
\hline
\end{tabular}

$E R$ estrogen receptor, $P R$ progesterone receptor, Her-2 human epidermal growth factor receptor 2, IDC infiltrating ductal carcinoma, $B C S$ breast conserving surgery, TNBC triple-negative breast cancer 
Table 4 Baseline data analysis of 1245 patients with different surgical mode

\begin{tabular}{|c|c|c|c|c|c|}
\hline Variables & BCS (\%) & Mastectomy (\%) & Radical Mastectomy (\%) & $x^{2}$ & P-value \\
\hline \multicolumn{6}{|l|}{ Race } \\
\hline White & $297(78.0 \%)$ & $204(80.0 \%)$ & $467(76.7 \%)$ & & \\
\hline Black & $57(15.0 \%)$ & $38(14.9 \%)$ & $95(15.6 \%)$ & 2.12 & 0.714 \\
\hline Other & $27(7.0 \%)$ & $13(5.1 \%)$ & $47(7.7 \%)$ & & \\
\hline \multicolumn{6}{|l|}{ Age } \\
\hline$\leq 35$ & $13(3.4 \%)$ & $16(6.3 \%)$ & $38(6.2 \%)$ & & \\
\hline $35<$ age $<60$ & $181(47.5 \%)$ & $132(51.8 \%)$ & $318(52.2 \%)$ & 8.373 & 0.079 \\
\hline$\geq 60$ & 187 (49.1\%) & 107 (42.0\%) & $253(41.5 \%)$ & & \\
\hline \multicolumn{6}{|l|}{ Grade } \\
\hline 1 & $34(8.9 \%)$ & $20(7.8 \%)$ & $45(7.4 \%)$ & 6.528 & 0.163 \\
\hline 2 & $173(45.4 \%)$ & $129(50.6 \%)$ & $258(42.4 \%)$ & & \\
\hline $3-4$ & $174(45.7 \%)$ & $106(41.6 \%)$ & $306(50.2 \%)$ & & \\
\hline \multicolumn{6}{|l|}{ Laterality } \\
\hline Left & $209(54.9 \%)$ & $130(51.0 \%)$ & $317(52.1 \%)$ & 1.115 & 0.573 \\
\hline Right & $172(45.1 \%)$ & 125 (49.0\%) & $292(48.0 \%)$ & & \\
\hline \multicolumn{6}{|l|}{ Marital } \\
\hline Married & $206(54.1 \%)$ & $138(54.1 \%)$ & $318(52.2 \%)$ & & \\
\hline Unmarried & $175(45.9 \%)$ & $117(45.9 \%)$ & $291(47.8 \%)$ & 0.438 & 0.803 \\
\hline \multicolumn{6}{|l|}{ Ethnic origin } \\
\hline Spanish-Hispanic-Latino & $43(11.3 \%)$ & $23(9.0 \%)$ & $70(11.5 \%)$ & 1.205 & 0.547 \\
\hline Non-Spanish-Hispanic-Latino & $338(88.7 \%)$ & $232(91.0 \%)$ & $539(88.5 \%)$ & & \\
\hline \multicolumn{6}{|l|}{ Histology } \\
\hline IDC & $326(85.6 \%)$ & $201(80.0 \%)$ & $49(77.0 \%)$ & 5.163 & 0.076 \\
\hline Non-IDC & $55(14.4 \%)$ & $54(20.0 \%)$ & $113(33.0 \%)$ & & \\
\hline \multicolumn{6}{|l|}{ Tstage } \\
\hline $\mathrm{T} 1$ & 91 (23.9\%) & $21(8.2 \%)$ & $41(6.7 \%)$ & 158,845 & $<0.001$ \\
\hline $\mathrm{T} 2$ & $22(58.3 \%)$ & $109(42.7 \%)$ & $238(39.10 \%)$ & & \\
\hline T3 & $37(9.7 \%)$ & $59(23.1 \%)$ & $146(24 \%)$ & & \\
\hline $\mathrm{T} 4$ & $31(8.1 \%)$ & $66(25.9 \%)$ & $184(30.20 \%)$ & & \\
\hline \multicolumn{6}{|l|}{ Nstage } \\
\hline No & $126(33.1 \%)$ & $52(20.4 \%)$ & $30(4.9 \%)$ & & \\
\hline N1 & $133(34.9 \%)$ & $124(48.6 \%)$ & $206(33.80 \%)$ & 192.317 & $<0.001$ \\
\hline N2 & $67(17.6 \%)$ & $41(16.10 \%)$ & $153(25.10 \%)$ & & \\
\hline N3 & $55(14.4 \%)$ & $38(14.90 \%)$ & $220(36.10 \%)$ & & \\
\hline \multicolumn{6}{|l|}{ Radiation } \\
\hline Yes & $22(60.1 \%)$ & $124(48.6 \%)$ & $351(57.60 \%)$ & & \\
\hline No & 15 (39.9\%) & $131(51.40 \%)$ & $258(42.40 \%)$ & 8.765 & 0.012 \\
\hline \multicolumn{6}{|l|}{ Chemotherapy } \\
\hline Yes & $20(54.9 \%)$ & $171(69.50 \%)$ & $423(67.10 \%)$ & & \\
\hline No & 17 (45.1\%) & $84(30.50 \%)$ & 186 (32.90\%) & 22.744 & $<0.001$ \\
\hline \multicolumn{6}{|l|}{ Subtype } \\
\hline $\mathrm{ER}+/ \mathrm{HER} 2-$ & $276(72.4 \%)$ & 177 (69.4\%) & 416 (68.3\%) & & \\
\hline $\mathrm{ER}+/ \mathrm{HER} 2+$ & $54(14.2 \%)$ & $34(13.3 \%)$ & 101 (16.6\%) & 6.514 & 0.368 \\
\hline HER2 + & 15 (3.9\%) & $11(4.3 \%)$ & 35 (5.7\%) & & \\
\hline TNBC & 36 (9.4\%) & $33(12.9 \%)$ & 57 (9.4\%) & & \\
\hline \multicolumn{6}{|l|}{$E R$} \\
\hline Positive & 329 (86.4\%) & 207 (81.2\%) & $514(84.4 \%)$ & 3.101 & 0.212 \\
\hline Negative & $52(13.6 \%)$ & $48(18.8 \%)$ & 95 (15.6\%) & & \\
\hline$P R$ & & & & & \\
\hline
\end{tabular}


Table 4 (continued)

\begin{tabular}{lcccr}
\hline Variables & BCS (\%) & Mastectomy (\%) & Radical Mastectomy (\%) & X $^{2}$ \\
\hline Positive & $281(73.8 \%)$ & $176(69.0 \%)$ & $429(70.4 \%)$ & 1.97 \\
Negative & $100(26.2 \%)$ & $79(31.0 \%)$ & $180(29.6 \%)$ & 0.373 \\
HER2 & & & & \\
Positive & $69(18.1 \%)$ & $45(17.6 \%)$ & $136(22.3 \%)$ & 3.786 \\
Negative & $312(81.9 \%)$ & $210(82.4 \%)$ & $473(77.7 \%)$ & 0.151 \\
\hline
\end{tabular}

$E R$ estrogen receptor, $P R$ progesterone receptor, Her-2 human epidermal growth factor receptor $2, I D C$ infiltrating ductal carcinoma, $B C S$ breast conserving surgery, $T N B C$ triple-negative breast cancer

the possibility of incomplete or inaccurate claim entry. The tumor burden of patients selected for surgery was relatively low, which was also a part of the surgical bias and might affect the results [37].

\section{Conclusion}

In conclusion, this study shows that primary surgery could improve the prognosis and OS of De novo stage IV $\mathrm{BC}$ patients with bone metastasis only. Under the premise of low tumor burden and comprehensive treatment, BCS is a better choice.

\begin{abstract}
Abbreviations
BC: Breast cancer; TNBC: Triple negative breast cancer; BCS: Breast conserving surgery; SEER: National Cancer Institute surveillance, Epidemiology, and Results Database; OS: Overall survival; AJCC: American Joint Committee on Cancer; ER: Estrogen receptor; PR: Progesterone receptor; Her-2: Human epidermal growth factor receptor 2 .
\end{abstract}

\section{Acknowledgements}

We would like to thank SEER providing for the open database. The authors gratefully acknowledge the whole staff of the Department of Science and Education, Xiaogan Hospital affiliated to Wuhan University of Science and Technology, who generously provided supervision throughout the duration of the study. In addition, we would like to thank the Foundation of Hubei Provincial Health Commission very much for assistance with the fund.

\section{Authors' contributions}

Research design: PP, YJC, HCH. Acquisition and analysis of data: XC, YHL, TYH. $X C, Y H L$ and TYH drafted the manuscript. Interpretation of data: PP, LJW, YJC. PP, YJC and $\mathrm{HCH}$ critically revised the manuscript for important intellectual content. All authors read and approved the final manuscript.

\section{Funding}

This study was supported by the Foundation of Hubei Provincial Health Commission (WJ2018H0112).The funders had no role in the design of the study and collection, analysis, and interpretation of data and in writing the manuscript.

\section{Availability of data and materials}

We received permission from the National Cancer Institute, US to access the research data file in the SEER program (Accession number 13705-Nov2019). The datasets analyzed during the current study are available in the SEER repository (SEER*Stat Version 8.3.6) (https://seer.cancer.gov/). The datasets used and/or analysed during the current study are also available from the corresponding author on reasonable request.

\section{Declarations}

Ethics approval and consent to participate

Not applicable.

\section{Consent for publication}

Not applicable.

\section{Competing interests}

The authors declare that they have no conflict of interest.

\section{Author details}

${ }^{1}$ Department of Breast and Thyroid Surgery, Xiaogan Hospital Affiliated to Wuhan University of Science and Technology, Square Road No. 6 Xiaogan, Hubei, China. ${ }^{2}$ School of Medicine, Jianghan University, 8 Xuefu Road, Wuhan Economic and Technological Development Zone, Wuhan, Hubei, China. ${ }^{3}$ Department of Breast Surgery, The First Affiliated Hospital of Chongqing Medical University, 1 Youyi Road, Yuanjiagang, Yuzhong, Chongqing, China ${ }^{4}$ Department of Breast Surgery, Jingzhou Central Hospital, No. 60 Jingjing Road, Jingzhou, Jingzhou, Hubei, China.

Received: 22 November 2020 Accepted: 15 October 2021

Published online: 26 October 2021

\section{References}

1. Siegel RL, Miller KD, Jemal A. Cancer statistics, 2020. CA Cancer J Clin. 2020;70(1):7-30.

2. Liede A, Jerzak KJ, Hernandez RK, Wade SW, Sun P, Narod SA. The incidence of bone metastasis after early-stage breast cancer in Canada. Breast Cancer Res Treat. 2016;156(3):587-95.

3. Jensen A, Jacobsen JB, Nrgaard M, Yong M, Fryzek JP, Srensen HT. Incidence of bone metastases and skeletal-related events in breast cancer patients: a population-based cohort study in Denmark. BMC Cancer. 2011;11(1):1-6. https://doi.org/10.1186/1471-2407-11-29.

4. Filippiadis D, Mavrogenis AF, Mazioti A, Palialexis K, Megaloikonomos PD, Papagelopoulos PJ, et al. Metastatic bone disease from breast cancer: a review of minimally invasive techniques for diagnosis and treatment. Eur J Orthop Surg Traumatol. 2017;27(6):729-36.

5. CardosoF, Costa A, Senkus E, Aapro M, André F, Barrios CH, et al. 3rd ESO-ESMO international consensus guidelines for Advanced Breast Cancer (ABC 3). The Breast 2017:244-259.

6. Gradishar WJ, Anderson BO, Abraham J, Aft R, Agnese D, Allison KH, Blair SL, et al. Breast cancer, Version 3.2020, NCCN Clinical Practice Guidelines in Oncology. J Natl Compr Cancer Netw. 2020;18(4):452-78.

7. Rapiti E, Verkooijen HM, Vlastos G, Fioretta G, Neyroud-Caspar I, Sappino AP, et al. Complete excision of primary breast tumor improves survival of patients with metastatic breast cancer at diagnosis. J Clin Oncol. 2006;24:2743-9. 
8. Gnerlich J, Jeffe DB, Deshpande AD, Beers C, Zander C, Margenthaler $J$ A. Surgical removal of the primary tumor increases overall survival in patients with metastatic breast cancer: analysis of the 1988-2003 SEER data. Ann Surg Oncol. 2007;14(8):2187-94.

9. Rao R, Feng L, Kuerer HM, Singletary SE, Bedrosian I, Hunt KK, et al. Timing of surgical intervention for the intact primary in stage IV breast cancer patients. Ann Surg Oncol. 2008;15(6):1696-702.

10. Bafford AC, Burstein HJ, Barkley CR, Smith BL, Lipsitz S, Iglehart JD, et al. Breast surgery in stage IV breast cancer: impact of staging and patient selection on overall survival. Breast Cancer Res Treat. 2009;115(1):7-12.

11. Harris E, Barry M, Kell MR. Meta-analysis to determine if surgical resection of the primary tumour in the setting of stage IV breast cancer impacts on survival. Ann Surg Oncol. 2013;20(9):2828-34.

12. Rashid O, Nagahashi M, Ramachandran S, Graham L, Yamada A, Spiegel $S$, et al. Resection of the primary tumor improves survival in metastatic breast cancer by reducing overall tumor burden. Surgery. 2013;153(6):771-8.

13. AlJohani B, AlMalik O, Anwar E, Tulbah A, Alshabanah M, AlSyaed A, et al. Impact of surgery on survival in stage IV breast cancer. Breast J. 2016:22(6):678-82.

14. Thomas A, Khan SA, Chrischilles EA, Schroeder MC. Initial surgery and survival in stage IV breast cancer in the United States, 1988-2011. JAMA Surg. 2016;151(5):424-31.

15. Vohra NA, Brinkley J, Kachare S, Muzaffar M. Primary tumor resection in metastatic breast cancer: a propensity-matched analysis, 1988-2011 SEER data base. Breast J. 2018;24(4):549-54

16. King TA, Lyman J, Gonen M, Reyes S, Hwang ESS, Rugo HS, Liu MC, et al. A prospective analysis of surgery and survival in stage IV breast cancer (TBCRC 013). J Clin Oncol. 2016. https://doi.org/10.1200/JCO.2016.34. 15_suppl.1006.

17. Badwe R, Hawaldar R, Nair N, Kaushik R, Parmar V, Siddique S, et al. Locoregional treatment versus no treatment of the primary tumour in metastatic breast cancer: an open-label randomised controlled trial. Lancet Oncol. 2015;16(13):1380-8.

18. Soran A, Ozmen V, Ozbas S, Karanlik H, Muslumanoglu M, Igci A, et al. Randomized trial comparing resection of primary tumor with no surgery in stage IV breast cancer at presentation: protocol MF07-01. Ann Surg Oncol. 2018;25(11):3141-9.

19. Edge SB, Compton CC. The American Joint Committee on Cancer: the $7^{\text {th }}$ edition of the AJCC cancer staging manual and the future of TNM. Ann Surg Oncol. 2010;17(6):1471-4.

20. Cristofanilli M, Budd GT, Ellis MJ, Stopeck A, Matera J, Miller MC, et al. Circulating tumor cells, disease progression, and survival in metastatic breast cancer. N Engl J Med. 2004;351(8):781-91.

21. Algizawy SM, Essa HH, El-Gezawy E, Omar NN, Sayed DM. Circulating tumor cells as an early predictive marker of disease progression in metastatic breast cancer patients. Cancer Biol. 2016;27(2):38-50.

22. Lang JE, Babiera GV. Locoregional resection in stage IV breast cancer: tumor biology, molecular and clinical perspectives. Surg Clin North Am. 2007;87(2):527-38.
23. Griffiths $C T$, Parker LM, Lee $S$, Finkler NJ. The effect of residual mass size on response to chemotherapy after surgical cytoreduction for advanced ovarian cancer: long-term results. Int J Gynecol Cancer. 2002;12(4):323-31.

24. Dauplat J, Boudec GL, Pomel C, Scherer C. Cytoreductive surgery for advanced stages of ovarian cancer. Semin Surg Oncol. 2000;19(1):42-8.

25. Danna EA, Sinha P, Gilbert M, Clements VK, Pulaski BA, Ostrand-Rosenberg S. Surgical removal of primary tumor reverses tumor-induced immunosuppression despite the presence of metastatic disease. Cancer Res. 2004;64(6):2205-11.

26. Rashid OM, Nagahashi M, Ramachandran S, Milstien S, Spiegel S, Takabe K. Resection of primary tumor improves survival in mouse metastatic breast cancer model. Cancer Res. 2010; 70(8) ISSN: 0008-5472.

27. Hallissey MT, Allum WH, Roginski C, Fielding JW. Palliative surgery for gastric cancer. Cancer. 1988;62(2):440-4.

28. Martin R, Paty P, Fong Y, Grace A, Cohen A, DeMatteo R, et al. Simultaneous liver and colorectal resections are safe for synchronous colorectal liver metastasis. J Am Coll Surg. 2003;197(2):233-41.

29. King T, Lyman J, Gonen M, Voci A, Boafo C, Hwang E, et al. TBCRC 013: a prospective analysis of the role of surgery in stage IV breast cancer. Cancer Res 2013;73(24 Suppl): Abstract nr P2-18-09. https://doi.org/10.1158/ 0008-5472.SABCS13-P2-18-09.

30. Khan SAM, Stewart AKM, Morrow MM. Does aggressive local therapy improve survival in metastatic breast cancer? Surgery. 2002;132(4):620-7.

31. McGuire KP, Eisen S, Rodriguez A, Meade T, Cox CE, Khakpour N. Factors associated with improved outcome after surgery in metastatic breast cancer patients. Am J Surg. 2009;198(4):511-5.

32. Liao N. HER2-positive breast cancer, how far away from the cure?-on the current situation of anti-HER2 therapy in breast cancer treatment and survival of patients. Chin Clin Oncol. 2016;5(3):41. https://doi.org/10. 21037/cco.2016.05.10 (PMID: 27265303).

33. Lv S, Wang Y, Sun T, Wan D, Sheng L, Li W, et al. Overall survival benefit from trastuzumab-based treatment in HER2-Positive metastatic breast cancer: a retrospective analysis. Oncol Res Treat. 2018;41(7-8):450-5.

34. Fornetti J, Welm AL, Stewart SA. Understanding the bone in cancer metastasis. J Bone Miner Res. 2018;33(12):2099-113.

35. Yanae M, Fujimoto S, Tane K, Tanioka M, Fujiwara K, Tsubaki M, et al. Increased risk of SSEs in bone-only metastatic breast cancer patients treated with zoledronic acid. J Bone Oncol. 2017;8:18-22.

36. Pulido C, Vendrell I, Ferreira AR, Casimiro S, Mansinho A, Alho I, Costa L. Bone metastasis risk factors in breast cancer. Ecancermedicalscience. 2017;11:715.

37. Olson JA Jr, Marcom PK. Benefit or bias? The role of surgery to remove the primary tumor in patients with metastatic breast cancer. Ann Surg. 2008;247(5):739-40.

\section{Publisher's Note}

Springer Nature remains neutral with regard to jurisdictional claims in published maps and institutional affiliations.

\footnotetext{
Ready to submit your research? Choose BMC and benefit from:

- fast, convenient online submission

- thorough peer review by experienced researchers in your field

- rapid publication on acceptance

- support for research data, including large and complex data types

- gold Open Access which fosters wider collaboration and increased citations

- maximum visibility for your research: over $100 \mathrm{M}$ website views per year
}

At $\mathrm{BMC}$, research is always in progress.

Learn more biomedcentral.com/submissions 